\title{
Hospício de doutores
}

\section{Asylum of doctors}

\author{
Marco Antonio Arantes
}

Centro Universitário Moura Lacerda, Ribeirão Preto (SP)

Rua André Veloni - Parque Bandeirantes 14090-450 Ribeirão Preto - SP - Brasil

marcoaarantes@uol.com.br

ARANTES, Marco Antonio. Hospício de doutores. História, Ciências, Saúde - Manguinhos, Rio de Janeiro, v.15, n.1, p.49-63, jan.-mar. 2008.

Escritor fervoroso, suburbano, negro, aguerrido, irônico, combativo, maldito e incompreendido por seus contemporâneos, Afonso Henriques de Lima Barreto (1881-1922) desceu ao inferno, conhecendo o desprezo de críticos, o fracasso como escritor e a indiferença familiar por sua vocação literária. Inquieto na dor, ríspido com os hipócritas, teve diante de si a tragédia da loucura, do alcoolismo e do preconceito. Como escritor, afogou-se em bebedeiras numa época em que assumir a condição de negro era um ato de coragem. A sua expressão consciente acerca dos médicos, dos loucos e da loucura constitui o ponto inicial deste artigo, baseado na experiência de vida do escritor no Hospício Nacional e no levantamento de trechos expressivos de sua produção literária. Tais temas orientam-se pela construção de uma estética da existência, cuja vida em questão é analisada como obra de arte.

Palavras-chave: Afonso Henriques de Lima Barreto (1881-1922); loucura; Hospício Nacional (Rio de Janeiro, Brasil).

ARANTES, Marco Antonio. Asylum of doctors. História, Ciências, Saúde - Manguinhos, Rio de Janeiro, v.15, n.1, p.49-63, Jan.-Mar. 2008.

An impassioned writer, suburbano, black, daring, ironic, combative, accursed, and misunderstood by his contemporaries, Afonso Henriques de Lima Barreto (1881-1922) traveled to hell, experiencing the scorn of critics, failure as a writer, and his family's indifference towards his literary vocation. Restless in his pain and heavy-handed with hypocrites, he grappled with the tragedies of madness, alcoholism, and prejudice at a time when assuming one's condition as a black was an act of courage. His conscious observations about doctors, the mad, and madness is the point of departure for this study, based on the writer's experience at the Hospicio Nacional and on a review of significant excerpts from Lima Barreto's literary production. The latter stands as an institutional and political issue and a criticism of the discourses that played important roles in preserving the structures of domination in the Old Republic.

Keywords: Afonso Henriques de Lima Barreto (1881-1922); madness; Hospício Nacional (Rio de Janeiro, Brazil). 
Se não houvesse médicos, nunca haveria doentes, nem esqueletos de mortos, doentes para serem esfolados e retalhados; pois a sociedade não começou com os doentes mas sim com os médicos.

Antonin Artaud, Loucura e magia negra

$\mathrm{T}$ ragédias sob tragédias. Um homem nu correndo pelos trilhos do subúrbio. Estados de angústia e asfixia humana intensa, delírios, alucinações, desprezo, perturbações, porres, desvarios, medos, gritos e amargura. Diante de tanta sordidez humana, o romancista Lima Barreto sentenciava: "Nós nunca somos senhores do rumo que deve tomar a nossa vida" (Lima Barreto, 1956h, p.96) Rosário de sofrimentos físicos e psicológicos, vida em eterna queda pelas sombras da quase demência, ainda assim conservou suas ilusões e a profunda amizade aos seres humanos, diante de um destino que sempre lhe impossibilitou conquistar em vida o reconhecimento literário. Lima Barreto, romancista de alma atormentada, em seus escombros ressoa uma triste e insólita história individual, cerceada de perto pela infatigável loucura. Destinado à tragédia, compôs uma obra pontilhada de viva verve irônica, na qual observa o próprio mergulho nas trevas malignas da loucura.

A loucura de Lima Barreto acompanha como uma sombra sua obra, mas não a reduz a um campo estéril de imagens desconexas e delírios desordenados, sobremaneira despojados de sentido social e estético. Sua enfermidade, que para frustração dos conformistas limitou-se em toda sua vida a uma lucidez desconcertante, não o coloca na galeria dos autênticos loucos. Afinal, perguntava Artaud com os olhos voltados a Van Gogh: "E o que é um autêntico louco?" (Artaud, 1983, p.133).

Ao realizar a leitura do romance Cemitério dos vivos e do diário de anotações Diário do hospício, ambos escritos pelo romancista carioca Lima Barreto, o leitor depara-se com escritos confessionais, anotações e reflexões significativas do escritor acerca da loucura, dos internos, do corpo administrativo e principalmente dos doutores do Hospício Nacional. Emerge dessas anotações uma delirante loucura que trará o tema do doutorismo para dentro do hospício, num vai-e-vem muitas vezes alucinado que conformará loucos e sãos como partes integradas em um mesmo espaço físico. Lima Barreto nos fala de negros, bêbados, leprosos, crianças, epilépticos, mulheres, um cortejo de indesejados aspirados para dentro do hospício e lá misturados aos sonhos positivistas como se fossem fantasmas.

O teor dessas duas obras delineia uma versão ficcional do verdadeiro calvário vivido pelo escritor durante sua breve passagem pelo Hospício Nacional, em fins de 1919. Em Cemitério dos vivos, as reflexões de Lima Barreto foram elaboradas sob o ponto de vista de um interno consciente das limitações da ciência e, principalmente, do incomensurável poder psiquiátrico que o hospício encerra. Ele se reconhece na condição de objeto em poder de médicos depositários de uma terminologia técnica incompreensível, compulsoriamente desprovido de direitos civis numa instituição que se mostra autoritária e arbitrária. Com efeito, o esforço do escritor não implicou refutar teorias psiquiátricas e substituí-las por outras, mas consistiu num questionamento sobre o infindo labirinto terminológico dos psiquiatras, que se julgavam capazes de compreender cientificamente os loucos. Essa postura científica positivista foi suficiente para que ironizasse médicos que consideravam os pacientes sempre anormais, independentemente da escolha pessoal do comportamento. Nessa esteira, elaborou uma crítica 
mordaz contra a ambigüidade do discurso médico que se colocava como soberano na questão da loucura e do tratamento e cura dos loucos. Daí o sentido moral do tratamento psiquiátrico, que se completava com o espaço terapêutico do hospício, no qual médicos se ocupavam em observar as diversas categorias de pessoas por meio da internação. Com o hospício a psiquiatria estenderá o seu campo de pesquisa, o que lhe proporcionará o aperfeiçoamento dos seus métodos, a depuração dos seus conceitos e, principalmente, a justificação das suas defesas profissionais.

O esforço de Lima Barreto consistiu em passar para o leitor sua vivência sobre as posturas médicas cientificamente respeitáveis, mas que, na verdade, expressavam caracterizações morais de comportamento. Tomando como base a experiência pessoal no hospício, questionou as muitas 'verdades científicas' apresentadas pelo corpo médico, que eram resumidas a uma ação arbitrária e humilhante sobre os pacientes. Em certo sentido, não escapou do romance, nem do diário do escritor, a incorporação psiquiátrica da loucura como objeto de estudo meramente técnico e científico, com valores morais condizentes ao status quo moral da sociedade que representava.

O escritor tem como alvo a crença no progresso e na ciência, muito em voga em fins do século XIX e que se disseminou rapidamente pelos setores políticos e científicos da República Velha, muito em razão da difusão de um ciência positivista, preocupada em abolir imaginações teológicas e ficções metafísicas. Na verdade, para Lima Barreto, o papel dos cientistas brasileiros muitas vezes resumia-se a importar teorias européias como se fossem dogmas, sem reflexões consistentes sobre o seu real conteúdo.

Historicamente sua internação contextualiza-se num período em que a loucura é reconhecida como 'doença mental' pela medicina social, processo que consolida definitivamente a psiquiatria no Brasil como ciência soberana em loucos e loucura. Esse processo acelera-se com a proclamação da República, em que a relação médico-paciente se radicaliza com a implantação de um poder tecnocientífico, com a finalidade de catalogar o comportamento diferencial dos chamados loucos.

Um dos aspectos mais interessantes de Cemitério dos vivos e Diário do hospício - este particularmente, em que o cotidiano da loucura asilada é o tema central - consiste numa severa crítica ao saber psiquiátrico, em especial dos médicos do Hospício Nacional, compostos por psiquiatras, legistas e médicos generalistas. Em Cemitério dos vivos, o protagonista do romance é examinado por vários médicos, que são misturados pelo escritor com os de sua primeira internação em 1914, no Hospício Nacional, e os médicos que o examinaram em sua segunda internação no mesmo hospício, em 1919. Tanto no romance quanto no diário não existe uma preocupação do escritor quanto aos nomes reais dos médicos, exceto em alguns casos em que os nomes verdadeiros foram mencionados, entre os quais os de Henrique Roxo, Juliano Moreira, Adauto Botelho e José Carneiro Airosa, todos em Diário do hospício. Em Cemitério dos vivos nenhum deles é citado, mas é possível identificá-los, comparando-se as descrições do romance com as do diário, por meio de comentários feitos a respeito dos exames médicos, ou mesmo mediante descrições sobre a aparência ou personalidade de cada médico.

Lima Barreto dedica uma atenção especial à figura médica, enfatizando principalmente a sua autoridade no interior da estrutura asilar. Em História da loucura, Michel Foucault (1995b) revela que os discursos médicos estariam muito mais comprometidos com valores morais do 
que científicos, como se pode constatar no prazo de internação do paciente, que era determinado, não pelo tempo de 'cura', mas pelo efeito do castigo no paciente advindo do arrependimento e do juízo.

Em Cemitério dos vivos, o primeiro médico a examinar o personagem protagonista Vicente Mascarenhas é identificado como o responsável pelo Pavilhão de Observação do Hospício. No dia seguinte, o exame ocorreria logo pela manhã, após Vicente passar a noite com pessoas consideradas miseráveis e indigentes, que eram levadas ao hospício em carros da polícia. Sobre esse médico, cujo nome não é revelado, o narrador fez a seguinte observação: "um moço, pois o era, em toda a linha, inteligente, simpático e bom..." (Lima Barreto, 1956a, p.160).

Em Diário do hospício, os médicos que examinaram Lima Barreto no Pavilhão de Observação atendiam pelos nomes de Henrique Roxo, Adauto Botelho e José Carneiro Airosa. O Pavilhão de Observação, assim como a Seção Pinel, era uma espécie de bode expiatório do regime republicano. Ali eram internadas as chamadas 'classes potencialmente perigosas' da população e que, segundo as autoridades, poderiam se insurgir por meio da ação política contra o governo. Misturavam-se nesse espaço mendigos, miseráveis, indigentes, ladrões, malandros, alcoólatras, enfim, aqueles que não tinham condições financeiras para pagar a própria estadia no hospício, como faziam os pensionistas. $\mathrm{O}$ tal pavilhão funcionava como um espaço de experimentações científicas, uma ponte entre a teoria científica e a prática psiquiátrica.

Não muito diferente do Pavilhão era a Seção Pinel, destinada a receber apenas os indigentes de sexo masculino. Em 1915, um ano depois da primeira internação de Lima Barreto no Hospício Nacional, a população dessa seção chegava a 461 pacientes, o que correspondia a $33,7 \%$ da população total e $60,5 \%$ da população geral de homens, que somava 761 indigentes. Este número expressa a preocupação do governo republicano com as inquietações sociais do período, marcado pelo aumento progressivo de pessoas desempregadas, quando não mal remuneradas, enfim, as pessoas que, vivendo à margem da sociedade, marcavam presença constante nas ocorrências policiais. Tais indivíduos eram encarados pela polícia como nocivos à ordem social, por 'colocar em risco' a população considerada mais culta e abastada da sociedade. Nada estranho, portanto, que entre 1907 e 1916 mais de dez mil internações tenham sido realizadas no Hospício Nacional, com a participação contínua e arbitrária da polícia.

No curto período em que esteve no Pavilhão de Observação, Lima Barreto foi examinado pelo doutor Adauto Botelho, que deu a entender ao escritor que logo lhe concederia a tão desejada liberdade. O desdém e a indiferença desse médico com o paciente seriam também abordados em Diário do hospício, vindo a ser o primeiro médico a ser mencionado. "Tratou-me ele com indiferença, fez-me perguntas e deu a entender que, por ele, me punham na rua" (Lima Barreto, 1956a, p.34). Já no romance Cemitério dos vivos, o mesmo episódio é recriado da seguinte maneira: "Fez-me perguntas, e senti mesmo que seu desejo era mandar-me embora" (p.178). No encontro com Botelho, notam-se as internações feitas pela polícia, instituição que colaborava consideravelmente para a superlotação no hospício: "Não há dúvida... Mas o senhor ou você - não me recordo - veio pela polícia, tem que se demorar um pouco" (p.178).

O segundo médico a examiná-lo atendia pelo nome de Henrique Roxo. A leitura do romance não permite situar o médico no Pavilhão de Observação ou na Seção Pinel, em virtude da passagem ser muito rápida e confusa, além de que, em nenhum momento, o escritor identifica claramente a seção onde se encontra. Em Diário do hospício, Henrique Roxo é caracterizado 
como um médico pedante e estúpido: "É bem curioso esse Roxo. Ele me parece inteligente, estudioso, honesto; mas não sei por que não simpatizo com ele. Ele me parece desses médicos brasileiros imbuídos de um ar de certeza de sua arte, desdenhando inteiramente toda a outra atividade intelectual que não a sua e pouco capaz de examinar o fato por si" (Lima Barreto, 1956a, p.35).

Depois de examinado pelo médico do Pavilhão de Observação, Lima Barreto foi transferido para a Seção Pinel, que era considerada a pior seção do hospício. A experiência dolorosa de ter passado ali alguns dias é relatada por Vicente Mascarenhas em Cemitério dos vivos, ao ser levado para lá por um enfermeiro português implicante, reforçando a imagem de brutalidade que recaía sobre tais enfermeiros, como decorria com os 'portugas' do Juqueri.

Vicente, personagem alter ego de Lima Barreto, ainda faria uma curiosa observação a respeito da iniqüidade dos tratamentos nessa ala do hospício, na sua maior parte ocupada por indigentes internados gratuitamente, o que tornava a seção chocante perante o número crescente de pessoas esquecidas no descaso do governo. O principal alvo era a multidão de humildes e miseráveis que constituíam a maior parte da população carioca do início do século, vítimas da injustiça social e da tradicional opressão governamental, fosse ela imperial ou republicana. Daí a transposição da discriminação social para dentro do hospício, onde as pessoas eram diferenciadas não apenas por seu comportamento clínico e posição social, mas também pela cor. No caso da Seção Pinel, a organização do espaço terapêutico tinha como propósito a sujeição e a correção dos indivíduos considerados miseráveis e 'perigosos', mediante uma ação cautelar de vigilância rígida e diferenciada.

Em alguns trechos do romance, Lima Barreto aborda a questão do controle médico sobre os corpos dos indivíduos internados, sobretudo a ação arbitrária dos médicos nos 'loucos', sendo cada um violado, humilhado e desprovido do domínio sobre seu próprio corpo. Reduzidos à condição de objetos da ciência, eram induzidos a acreditar que, como doentes mentais, o melhor era estar à mercê da infalível 'constatação científica'.

A temática da significação dos corpos para a ciência - o corpo cadáver - representa um componente essencial nas relações de poder na sociedade moderna e, como tal, constitui uma das questões primordiais nas análises de Michel Foucault sobre a loucura. Os corpos seriam concebidos para ser corrigidos, reformados, formados, controlados e disciplinados. Trata-se de um investimento político nos corpos dos indivíduos para torná-los dóceis e úteis, e para isso a medicina e a psiquiatria foram exemplares. Mediante o poder de manipular os corpos, o médico despontava como 'sacerdote do corpo', submetendo seus pacientes à sua 'autoridade científica'.

O domínio dos médicos sobre os corpos dos pacientes refletiu-se nas transferências do escritor para outras seções do Hospício. Em Cemitério dos vivos, por exemplo, o narrador explica que o desejo de ser transferido da Seção Pinel para a Seção Calmeil (destinada a pensionistas) justifica-se, sobretudo, pelo medo que passou a sentir pelo médico 'cheio de certezas' daquela seção do hospício, aquele que pretendia fazer crer que tudo poderia ser explicado em razão da 'infalibilidade científica'.

A respeito das constantes transferências mencionadas por Lima Barreto durante o transcorrer de Cemitério dos vivos, pode-se dizer que a mobilidade dos internados refletia um esforço médico de domesticação dos corpos, os quais, transformados em lugares de passagem, reduziam-se a 
corpos dominados, indefesos e passivos; corpos que, deslocados como objetos do Pavilhão de Observação para uma seção, e desta para outra, eram desprovidos quase que por completo de liberdade. Lembremos contudo que Lima Barreto lançou mão de certos recursos, como suas relações pessoais e seu prestígio de escritor, para obter a transferência para uma seção que lhe fosse mais conveniente.

Dois outros motivos levariam o escritor a ver com bons olhos a transferência para a Seção Calmeil: em primeiro lugar, ele se livraria da incômoda situação de promiscuidade com os indigentes da Seção Pinel; em segundo lugar, poderia freqüentar a biblioteca instalada naquela seção. Esta tinha sido construída como alternativa de lazer para os pensionistas de primeira e segunda classes, sabendo-se que, no Hospício, esse grupo seria poupado de realizar trabalhos manuais, ao contrário dos pobres da Seção Pinel. Constavam na biblioteca autores como Gérard de Nerval, Bourget, Dostoiévski, Félix Joubleau, Merejcóvski, Plutarco, Colbert e Renan, sendo este último, aliás, citado na epígrafe de Triste fim de Policarpo Quaresma.

A descrição das obras que compunham a biblioteca - que abria em dias determinados encontra-se ao final da obra, e dava prosseguimento ao hábito peculiar do escritor de descrever bibliotecas, como as dos personagens Isaías Caminha, Major Quaresma e Fausto Carregal, do conto "A biblioteca".

Convém observar que, entre os vários médicos que examinaram o escritor, apenas dois, Humberto Gotuzzo (cujo nome é citado apenas na entrevista) e Juliano Moreira, não foram duramente criticados pelo escritor. O primeiro, que despertou a simpatia do escritor, embora com ressalvas, é descrito como um típico 'botafogano', pejorativo criado por Lima Barreto para ironizar os indivíduos europeizados da época, atualmente reconhecidos como socialites ou grã-finos. Lima Barreto era contrário à depuração social pelo dinheiro e referia-se com sarcasmo a essas pessoas, por considerá-las vaidosas, dadas à luxúria e com manias de aristocracia e grandeza. Mas parece ter relevado esse aspecto da personalidade do médico, talvez por ter este lhe cedido o gabinete para escrever as primeiras anotações de seu diário:

Também era muito conhecido meu, desde menino, eu tive grande surpresa, em ficar encantado com ele e um imenso prazer em julgá-lo de outro modo. Tinha-o por dandy, por fútil, algo pedante e, mais do que os outros, que éramos, francamente conhecidos e ele podia com certa razão ter motivos de queixa de mim, eu fui à sua presença com certo temor e sem nenhuma segurança da minha atitude. (Lima Barreto, 1956a, p.220-221)

A Seção Calmeil, onde Lima Barreto foi examinado por Humberto Gotuzzo, destinava-se, conforme já mencionado, aos pacientes pensionistas, pessoas tidas como mais 'educadas' socialmente. O número elevado de pensionistas ali devia-se, sobretudo, às quatro classes em que os pensionistas eram 'classificados'. Teixeira Brandão (1897) ressalta também que, na época em que as irmãs de caridade detinham o poder dentro do hospício, a direção somente aceitava pessoas 'protegidas pelos poderosos', pensionistas que muitas vezes nada pagavam ao hospício, inviabilizando e dificultando financeiramente a internação dos chamados loucos indigentes: "O hospício continuava fechado aos indigentes que não tinham tido fortuna de enlouquecer no Hospital da Misericórdia, ou não tinham bons padrinhos" (p.16).

A mesma crítica formulada por Teixeira Brandão é expressa pelo personagem Vicente Mascarenhas, que se dizia surpreso em encontrar, na Seção Pinel, pessoas com condições 
financeiras condizentes para pagar o próprio tratamento, mas que preferiam deixar para o Estado esse encargo financeiro. Vicente Mascarenhas considera tal comportamento prejudicial para o tratamento dos verdadeiros pobres: "O Estado, recebendo-os como loucos, por mais mínima que fosse, o seu primeiro cuidado devia ser apoderar-se dessa pensão para o seu tratamento. Evitava que eles fossem tratados abaixo de sua condição, aumentava a renda do estabelecimento e dava enchanças para melhorar o tratamento dos verdadeiros pobres" (Lima Barreto, 1956a, p.222). Lima Barreto colocava-se frontalmente contrário à divisão de classes aplicada no Hospício, em razão de os obstáculos institucionais e mesmo judiciais impedirem que um indigente usufruísse das mesmas regalias dos pensionistas, que entre outras coisas estavam dispensados dos serviços de limpeza e manutenção do edifício. Assim, ao propor o pagamento a pessoas com melhores condições sociais, pensava-o no intuito de humanizar o tratamento oferecido aos indigentes, 'diminuindo e corrigindo' as distâncias sociais dentro do hospício: "Tem-se em conta do doente mais rico, mais importante, o que mete medo aos guardas, aos médicos, as pessoas superiores" (p.112).

Com a Proclamação da República e a emancipação médica dentro do hospício, reafirmouse, com o artigo número 6 da Lei dos Alienados, que indivíduos pobres e miseráveis com 'tendência' à desordem representariam o mais sério obstáculo à ordem pública. O alvo prioritário das internações no Hospício se modifica com a vinda da República, e muitas regulamentações foram fixadas para atender às reivindicações médicas, que exigiam, entre outras coisas, a reclusão dos loucos que circulavam livremente pelas ruas da capital. Na verdade, o governo republicano - ao contrário do monárquico, teve uma maior aproximação com os médicos psiquiatras, no que se refere ao processo de institucionalização do estatuto da doença mental no país, e acatou a idéia de que lhe cabia gerir a assistência dos alienados. Essa intervenção do Estado premiava as atuações dos diretores Nuno de Andrade e Teixeira Brandão em debates na Câmara e no Senado, pois ambos teriam convencido políticos republicanos da necessidade de estatização do Hospício Dom Pedro II (que passaria a chamar-se Hospício Nacional, após se separar da Santa Casa de Misericórdia). Esse fato foi determinante para a consolidação da psiquiatria como ciência majoritária em questões referentes à loucura, sendo um passo decisivo para colocar em marcha as regras de controle social e normalização médica com o consentimento do poder jurídico, que de forma direta ou indireta viabilizava legalmente a prática psiquiátrica nos hospícios.

O primeiro aspecto da lei a ser destacado refere-se à determinação contida no seu artigo 1 . Que reafirmava o princípio estabelecido pelo artigo 13 do decreto de fevereiro de 1890 que criou a assistência médico e legal de alienados -, segundo o qual, como vimos, o alvo prioritário das internações eram os alienados considerados perigosos, ou seja, aqueles que colocassem em risco a ordem pública ou a segurança das pessoas (decreto 1.132, , art. $1^{\circ}, 22$ dez. 1903). (Engel, 1995, p.352)

Além do Pavilhão de Observação da Seção Pinel e da Seção Calmeil, outras seções do hospício são mencionadas pelo narrador ao longo do romance. O hospício, segundo Vicente Mascarenhas, era dividido da seguinte forma:

A administração do hospício é feita segundo seções e pavilhões, à testa das quais tem um alienista e mais médicos. Segundo depreendi, as seções principais do hospício 
propriamente são quatro: Pinel e Calmeil, para homens; e Morel e Esquirol, para mulheres. Além destas, há outras especiais, para epilépticos, para crianças retardadas, hígidas e epilépticas, para tuberculosos, etc., cada qual com o nome da sumidade nacional ou estrangeira. O Pavilhão de Observação, por excelência, é o de observação, que tem uma organização sui generis, depende do hospício, da polícia e da Faculdade de Medicina, cujo lente de psiquiatria é o seu diretor, sem nenhuma dependência ou subordinação ao do hospício, dependendo, entretanto, o resto do pessoal subalterno e fornecendo este estabelecimento tudo o mais. (Lima Barreto, 1956a, p.221)

O primeiro aspecto a observar no trecho é a constatação de uma seção reservada às mulheres, espaço que conservava em sua entrada principal uma estátua de Esquirol, médico que se tornou conhecido pelos tratamentos morais e por ter transformado as internações no meio mais eficaz de repressão e submissão dos doentes. A divisão entre os sexos foi uma das prioridades dos médicos em relação à distribuição espacial dos pacientes do Hospício Nacional. Fundamental para gerar mais eficácia do tratamento da loucura, ela era invariavelmente dividida em diferentes modalidades e categorias, em doentes e doenças, além de ser a loucura das mulheres distinguida da dos homens. Com a divisão espacial, os médicos tentavam evitar o contato sexual entre os loucos, em nome de uma prevenção à promiscuidade, fator que consideravam prejudicial para o tratamento das diversas gradações da loucura.

Além dos indigentes da Seção Pinel, da Seção Esquirol e dos vários pensionistas da Seção Calmeil, havia também, no Hospício, dois pavilhões reservados para os epilépticos: os Pavilhões Griesinger e Guislain. Durante muitos anos a epilepsia foi classificada como doença gravíssima, cujos sintomas poderiam levar os homens a cometer desatinos da pior espécie. Foi pensando num processo de ordenamento social que muitos psiquiatras entenderam que os epilépticos (que ainda preservavam a imagem de personagens típicos do desatino) deveriam ser impedidos de viver soltos pelas ruas, por tratarem-se de pessoas perigosas, traiçoeiras e maldosas.

A identificação da epilepsia como forma de manifestação de desatino pode também ser encontrada em Lima Barreto, quando descreve o comportamento do companheiro de dormitório que, a seu ver, tinha uma "sanidade ilusória": "Há alguns que não são aparentemente doentes, mas que em dados momentos se denunciam em contrário. Os epilépticos, os sujeitos a certas manias que tem um delírio de tempos em tempos" (Lima Barreto, 1956a, p.114).

No instante em que os epilépticos eram reconhecidos pela sociedade, o procedimento mais habitual era isolá-los e confiná-los em hospícios. Por mais estranho que possa parecer, passavam a receber um estatuto muito semelhante ao dos alcoólatras, que eram avaliados segundo normas sociais de incapacitação inata para a vivência no ambiente social.

Em relação à seção destinada a abrigar as crianças, o escritor faz uma rápida menção no romance, quando relata alguns passeios dominicais de Vicente Mascarenhas pela chácara do Hospício: "A tarde continuava bela e agradável. Em meio do caminho, encontramos bandos de crianças loucas, de menos de dez anos, que iam brincar, sob a vigilância de uma enfermeira estrangeira, alemã, parecia. Havia de todas as cores, e todas eram feias, algumas mesmo aleijadas" (Lima Barreto, 1956a, p.196).

Os motivos que justificavam a existência de um pavilhão voltado exclusivamente para crianças decorriam de uma série de críticas levantadas na época, pelo Jornal do Commrcio, contra Pedro Dias Carneiro, que dirigia o serviço de assistência aos alienados em 1902 e teria 
sido acusado de permitir promiscuidades entre adultos e crianças no Hospício Nacional. A gravidade da situação forçou a direção da instituição a reservar uma ala para acolher as crianças do sexo masculino, embora a inauguração tenha ocorrido somente após dois anos. O chamado Pavilhão Bourneville, a exemplo do modelo francês aperfeiçoado por Bourneville, ensinava as crianças a ler, escrever e ter boas maneiras à mesa. Em 1908, sob a administração de Juliano Moreira, ele seria ampliado em virtude do crescimento vertiginoso de internações de 'pequenos alienados'.

Lima Barreto era conhecido como andarilho incansável, gostava de percorrer longas distâncias pelas ruas do Rio de Janeiro, como do centro ao subúrbio, ou da Gávea ao Leblon. Na galeria de personagens do escritor, Gonzaga de Sá foi o personagem que certamente melhor incorporou esse peculiar hábito do escritor. Essa mesma mania ambulatória de Gonzaga também é encontrada em Vicente Mascarenhas, em seus passeios pelas seções do Hospício, quando matava o tempo para recordar os sonhos e projetos não realizados. Combinava assim a lembrança dos sonhos com a prescrição médica da época, que acreditava na terapêutica do movimento como acesso à cura da loucura, preenchendo o tempo com caminhadas, que traduziriam movimento, relaxamento, curiosidade, novidade, variedade e plenitude. Numa dessas andanças, em companhia de um português chamado Misael, Mascarenhas relata seu primeiro contato com o Pavilhão Márcio Néry, reservado aos leprosos, que na sua visão tingiase pelas cores da degradação e da morte:

Fomos ver outra pior, a horrorosa morféia, que, junto com a loucura, é para juntar o horror até ao mais alto grau. Uma deforma, degrada o pensamento; a outra, o corpo, o rosto sobretudo. Não quis olhar onde estavam alojados os lázaros dementes. Era numa barraca de campanha, erguidas sobre copeques, e cujas bordas eram presas por pedregulhos respeitáveis. A sua moradia era provisória; a morte não tardaria em levá-los. (Lima Barreto, 1956a, p.195)

Quanto às funções de vigilância no Hospício Nacional, no transcorrer de Cemitério dos vivos e Diário do hospício o autor afirma que ela era realizada por enfermeiros, guardas, guardas rondantes, inspetores ${ }^{1}$, chefe de enfermaria, enfermeiro-mor e até mesmo pelo chefe de serviço.

Dias, desde esse tempo, e parece que já mesmo antes, nunca largou esse ofício de pajear malucos. Não é dos mais agradáveis e é preciso, além de paciência e resignação para aturá-los, uma abdicação de tudo aquilo que faz o encanto da vida de todo o homem ... Ouvir durante o dia e a noite toda a sorte de disparates, receber as reclamações mais desarrazoadas e infantis, adivinhar as manhas, os seus truques e dissimulações - tudo isto e mais o que se pode facilmente adivinhar, transforma a vida desses guardas, enfermeiros, num verdadeiro sacerdócio (Lima Barreto, 1956a, p.42).

Quando o autor refere-se ao relacionamento entre enfermeiros e pacientes, não falava propriamente da relação construída na base da repressão, do castigo e da punição, mas da autoridade. É preciso frisar que a vigilância dos pacientes estava a cargo dos enfermeiros do Hospício, de modo que essa atividade mediava a relação entre o médico e o doente.

Ainda a respeito dos enfermeiros, relata Lima Barreto em Cemitério dos vivos que estes eram pessoas com sérios riscos de contaminação pela loucura. Em determinado momento, perguntase: "Haverá contágio da loucura? Creio que sim. Ambiência do Hospital" (Lima Barreto, 1956a, 
p.102). Nota-se claramente, por parte do romancista, a recusa de uma suposta explicação genética para a loucura.

Entre as possíveis causas da loucura do personagem Vicente Mascarenhas, que em muito reflete a vida real do escritor, a mais curiosa diz respeito à perspectiva negativa do escritor em relação aos relacionamentos afetivos. Essa postura negativa em relação ao amor é um dos temas recorrentes em Cemitério dos vivos, que na obra também se associa aos temas do alcoolismo e da loucura. Parece ser o caso de um trecho esboçado em Diário do hospício, em que o amor é dotado do poder de salvar os loucos da morte mas não da loucura, pois eles estão "na mão de um poder que é mais forte do que a morte. A esta, dizem, vence o amor; a loucura, porém, nem ele" (Lima Barreto, 1956a, p.77). Esta questão é problematizada ao longo da narrativa memorialista de Diário do hospício, concomitante ao tema da loucura, reavaliando o autor sua trajetória intelectual, os seus erros, sofrimentos e fracassos no campo do amor, que, levados ao excesso, passaram a ser vistos como uma das causas prováveis da loucura. A dúvida persiste nas páginas de Diário do hospício, em trecho que se reporta a uma biografia de Abélard, escrita por Lewis, célebre biógrafo de Goethe, e a um manuscrito de Heloísa. A leitura feita por Tito Flamínio ${ }^{2}$ surge como um ponto crucial para as deduções do autor: "Eu me indago, de mim para mim se, por acaso não é o amor que me corrói. Mas vejo bem que não. Passei a idade de tê-los, fugindo dele, para que não me criasse sofrimento e não prejudicasse a minha ambição de glória. A própria Heloísa achava-o nocivo nos homens de pensamento; é verdade que ela também achava o seu Abelardo virtuoso" (Lima Barreto, 1956a, p.68).

Aos guardas do Hospício Nacional, Lima Barreto reservava certa dose de simpatia, com exceção de alguns autoritários, que na malsã vaidade de mandar submetiam os pacientes a diversas atividades no hospício. É importante observar que o trabalho contribuía para a ordem asilar como elemento de controle e disciplina dos loucos, ou seja, a realização de trabalhos domésticos pelos pacientes do hospício visava também o controle terapêutico dos chamados loucos.

Lima Barreto dá ênfase particular ao aspecto punitivo e disciplinar das atividades realizadas pelos internos do hospício. É o caso dos serviços de limpeza realizados contra a vontade do paciente, em razão do cumprimento de ordem vindas de guardas truculentos e autoritários: "Quando o guarda que nos veio abrir porta, deu-me uma vassoura e um pano com que eu ajudasse a ele e outros a baldear o quarto-forte e a varanda, não fiz nenhum movimento de repulsa. Tomei os objetos e cumpri docilmente o mandato. O que me aborreceu, porém, foi a falta de forças e hábito de abaixar-me, para realizar tão útil serviço" (Lima Barreto, 1956a, p.156).

A ambigüidade do trabalho como utilização terapêutica fica mais clara quando se constata que, se de um lado ele era utilizado como um instrumento de 'cura' da doença mental, em outro plano era visto como uma forma ilusória de reabilitação moral do louco, que era taxado de incapaz para o trabalho. Essa estranha ambigüidade gerou uma economia de punição que se servia da mão-de-obra dos pacientes em serviço de costuras, bordado, móveis, calçados e colchas, em oficinas instaladas dentro do Hospício Nacional. ${ }^{3}$ A distribuição dos diferentes serviços obedecia a critérios não apenas de sexo, mas também de aptidão profissional do doente, tipo de insanidade e, sobretudo, condição social do internado. A economia se justapunha a uma divisão social que reservava aos pacientes pobres os serviços habituais de 
jardinagem, limpeza, lavanderia, serviços de obras e trabalho agrícola, restando aos pacientes ricos (que não eram obrigados a trabalhar), a simples incumbência de fazer leituras de livros e jornais na biblioteca. O que estava em jogo era a economia de recursos que os pacientes poderiam proporcionar à administração do Hospício, na realização dos serviços destinados aos funcionários habituais, embora o trabalho fosse visto como um bem para a alma e para o físico do doente ocioso e condição essencial para a cura.

Nas anotações de Diário do hospício, fica claro que o mesmo guarda que lhe dava ordens para varrer o pátio e lavar o banheiro também lhe aplicava um banho de ducha de chicote. $\mathrm{O}$ banho coletivo faria o personagem recordar-se do banho de vapor que Dostoievski tomou num banheiro público na Rússia e relatado numa passagem do romance Recordações da casa dos mortos:

Voltei para o pátio, meu Deus! Estava ali que nem um peru, no meio de muitos outros, pastoreado por um bom português, que tinha um ar rude, mas doce e compassivo, de camponês transmontano. Ele já me conhecia da outra vez. Chamava-me você e me deu cigarros. Da outra vez, fui para a casa-forte e ele me fez baldear a varanda, lavar o banheiro, onde me deu um excelente banho de ducha de chicote. Todos nós estávamos nus, as portas abertas, e eu tive muito pudor. Eu me lembrei do banho de vapor de Dostoiévski, na Casa dos Mortos. Quando baldeei, chorei; mas lembrei de Cervantes, do próprio Dostoiévski, que pior deviam ter sofrido em Argel e na Sibéria (Lima Barreto, 1956a, p.34-35).

Dostoiévski enfatiza, sobretudo a promiscuidade e a falta de higiene no banho de vapor que tinha tomado, como se pode observar nesse trecho do romance:

Por toda parte escorria imundície. Todos estavam como em bebedeira, numa espécie de letargia. Só se ouviam gritos e berros. Junto ao postigo, por onde serviam a freguesia passando baldes com água de ferver, havia aglomeração furiosa, a altercação e o reboliço sendo permanentemente, água se derramando sem cessar sobre os que estavam embaixo, à medida que os baldes iam passando. (Dostoiévski, 1988, p.111)

Tanto no romance quanto no diário, constata-se o desconhecimento do escritor em relação ao caráter punitivo e moral da aplicação do banho de ducha, exceto pela única reclamação que manifestou ao tê-lo que tomá-lo nu, com as portas do pátio abertas. Quanto à comparação da ducha de chicote com as caldeiras do inferno de Dostoiévski, pareceu-lhe a certa altura bem distinta a sua experiência, daquela experimentada pelo escritor russo4: "As duchas, principalmente as de chicote, deram-me um prazer imenso e, se fora rico, havia de tê-las em casa. Fazem-me saudades do pavilhão..." (Lima Barreto, 1956a, p.157). A ducha gelada aplicada no doente não se relacionava diretamente à autoridade do guarda ou do enfermeiro, mas à vontade do médico que tinha o poder de prescrever tratamentos - punições com banhos de ducha fria.

Na verdade, a técnica fantasista dos banhos de duchas, que seria resgatada por Pinel ${ }^{5}$ dentro de um contexto moral e punitivo, precede de uma duvidosa base científica sobre os poderes da água na cura da loucura. Se voltarmos ao passado, mais precisamente no século XVIII, veremos que a água, por ser a substância mais presente nos corpos, induziria a uma estranha crença científica segundo a qual ela teria o poder de purificar cérebros de pessoas acometidas pelas doenças dos nervos. Mais ainda: por estar presente em todos os corpos, a água funcionaria 
como um estabilizador ou regulador natural das mentes humanas. De maneira geral, o banho como meio terapêutico no tratamento da loucura oscilava entre punição e controle dos doentes, e era aplicado como forma eficiente de persuadir e conformar os pacientes quanto à orientação moral dos médicos do hospício.

Em Cemitério dos vivos, a loucura é separada e classificada por tipos como berradores, nudistas, imbecis e mutistas, com base nos sintomas e delírios dos doentes. De fato, o delírio é um signo de reconhecimento da loucura, de comportamento e verdade da loucura, embora a loucura alcance uma complexidade além deste tipo de manifestação. Há, conforme assinalou Lima Barreto, loucura sem delírio, como no caso do estudante de medicina internado que o escritor conheceu no Hospício Nacional: "Há muitas formas de loucura e algumas permitem aos doentes momentos de verdadeira e completa lucidez ... Dá-se o mesmo com a instrução, a educação. A loucura dá intervalos" (Lima Barreto, 1956a, p.59). Lima Barreto refere-se a manifestações de loucura em que o delírio não é evidente, o que não representa uma dificuldade suplementar para médicos que buscam nos gestos silenciosos dos loucos e nos comportamentos estranhos a essência da loucura. Embora tivesse salientado o aspecto da razão na loucura, a marca distintiva que mais lhe interessou foram os delírios, ao observar o comportamento dos internos no hospício. Em Diário do hospício, dos quase cinqüenta pacientes descritos pelo escritor, muitos foram analisados tendo como foco seus delírios. Em face disso, são várias as formas de loucura caracterizadas tomando-se por base o delírio, que salientam o aspecto desordenado e perturbado da atividade mental e intelectual dos doentes.

Quanto às perturbações do corpo, Lima Barreto menciona alguns casos curiosos, como o companheiro de dormitório que se comportava como uma estátua e ficava em pé o dia inteiro, e outros "que se recusavam a comer, rasgavam a roupa, e emporcalhavam-se de fezes e urina" (Lima Barreto, 1956a, p.207). A insensibilidade do doente em relação ao próprio corpo reflete o desinteresse e a apatia do interno contra o sistema que o exclui e o aniquila, e funciona como uma defesa do espaço de coação do hospício.

Os diálogos de Vicente Mascarenhas com vários internos do Hospício sublinham a linguagem confusa dos loucos, assim como reconhecem, na estrutura de seus discursos, a essência das verdades secretas do homem. Assim ocorre no diálogo do personagem com um velho nortista acometido de manias de perseguição, cujo delírio persecutório apresenta-se, para Mascarenhas, como signo integrante da loucura, por meio do qual seria possível desvendar os segredos da doença: "É um louco clássico, com delírio de perseguição e grandeza. É um homem inteligente, mas com cultura elementar, e o seu delírio, desde que não se interrogue pela base, parece à primeira vista a mais pura verdade" (Lima Barreto, 1956a, p.56). Figuram ainda nessa lista os que manifestavam delírios implícitos, incluindo os internos que 'não são aparentemente doentes', conforme os caracterizou numa passagem do romance. Nessa categoria incluíam-se os imitadores, os monomaníacos, os berradores, os dementes, os imbecis e, sobretudo, os militares uxoricidas que ficavam na Seção Nina Rodrigues, ala reservada exclusivamente para os militares considerados loucos.

As ponderações feitas por Lima Barreto aos militares (uxoricidas ou não) ${ }^{6}$ e ao Estado republicano explicam-se em razão da ditadura militar instalada pelos mesmos, e canalizavam uma contestação à forte influência do positivismo europeu na política nacional, principalmente com o ingresso de Benjamim Constant na Escola Militar, em 1872, após a Guerra do Paraguai. 
A rigor, a formulação crítica do escritor contra o positivismo tem como principal motivação o descrédito e a indiferença do novo regime em relação às classes populares, daí sua implacável crítica ao que chamava de falsa República, revelada em uma série de artigos e crônicas:

Na palavra sem retoques de Lima Barreto, liquidam-se o ideário dos pró-homens da República e o seu tom liberal-eufórico. A prova dos nove, o regime em pleno funcionamento apontara erro de cálculo. A República sonhada pelos Benjamim Constant e seus cadetes é uma oligarquia cheia de preconceitos que sustenta uma burocracia túrgida e sonsa. Ai dos desapadrinhados nesse imenso cabide de empregos que é a cidade do Rio de Janeiro. (Bosi, 1977, p.307)

Para o Lima Barreto, a reclusão associava-se a relações de poder com a função específica de anular o indivíduo por meio da sujeição dos corpos dos doentes à ordenação programada do tempo. O escritor identifica o controle do tempo inscrito na própria caracterização geográfica do hospício, na subdivisão temporal, fazendo com que o tempo de vida transforme-se em tempo de controle asilar:

Para mim, eram as mais tristes horas que passei no hospital, aquelas que vão da refeição até à hora do sono. Durante as outras, há sempre uma esperança para nos animar e sustentar o espírito: são as das refeições. Marca-se a vida daquelas horas vazias de que fazer, de ócio obrigado, mas cheias de tédio, por elas, mas, depois do jantar, não há mais nenhum marco no tempo que vai correr, senão o duvidoso do instante em que se concilie o sono. (Lima Barreto, 1956a, p.214)

Cemitério dos vivos simboliza uma metáfora de busca da própria imagem do destino dentro do hospício. Sincero e dissimulado, coloca a nu a própria vida, embora o autor não tenha se preocupado apenas em dar um depoimento de sua trajetória intelectual. Antes de tudo, quer deixar claro que todos os acontecimentos descritos dimensionam-se como ressonâncias de si mesmo e como compreensão de sua personalidade literária. Enclausurado nas paredes do Hospício, em muitos momentos mostrou-se avesso a ele, sem entender a lógica dos acontecimentos que se sucediam durante seus delírios. Atento às individualidades, em certas ocasiões esperou de médicos uma alternativa para sair da enrascada em que tinha se metido. Para ele faltava a amorosidade no hospício, ausência que sentia igualmente na na família e nas relações sociais em geral.

\section{NOTAS}

${ }^{1}$ Esclarece Juliano Moreira (1955), em "Notícia sobre a evolução da assistência a alienados no Brasil", que o cargo de inspetor havia sido criado em 19 de fevereiro de 1897 e tinha a função de superintender a parte científica e administrativa do hospício.

${ }^{2}$ Durante a elaboração de Diário do hospício, cuja leitura final resultou em Cemitério dos vivos, Lima Barreto ainda estava indeciso sobre o nome do protagonista do romance, ora chamando-o de Tito Flamínio, ora de Vicente Mascarenhas, sendo este último o nome escolhido para o personagem.

${ }^{3}$ Os serviços relacionados a tecidos tinham predominância entre mulheres; para os homens eram mais comuns os serviços de limpeza e manutenção do edifício. 


\begin{abstract}
${ }^{4}$ Segundo Alfredo Bosi (1994), a aproximação entre o romance Cemitério dos vivos e Recordações da casa dos mortos é possível "não tanto pela analogia da situação quanto pela sinceridade ardente do documento humano" (p.322).

${ }^{5}$ Segundo Michel Foucault (1995b, p.494), "com Pinel, o uso da ducha torna-se francamente judiciário; a ducha é a punição habitual do tribunal de simples polícia constituído permanentemente no asilo".

${ }^{6}$ Sobre os militares do período republicano, elencam-se as crônicas do escritor publicadas em Coisas do reino de Jambon (Lima Barreto, 1956g) - "Fábricas e arsenais bélicos" (p.170-172); "Os doutores militares da polícia", (p.168-170; "Na segunda classe" (p.188-189) - e a crônica publicada em Impressões de leituras (1956h), "Sobre uma obra de sociologia, (p.236-244).

${ }^{7}$ Com a temática da República, podemos destacar as crônicas publicadas em Feiras e mafuás (Lima Barreto, 1956c): "Feiras e mafuás" (p.21-28), "Simples reparo" (p.122-126), "Extravagâncias oficiais" (p.127-130); "A mudança do Senado" (p.219-223); "As reformas e os doutores" (p.229-240); "O encerramento do congresso" (p.273-275) e "Coerência" (p.200-202). A crônicas publicadas em Marginália (1956f) sobre o tema são: "São Paulo e os estrangeiros" (p.204-207); "15 de novembro" (p.35-36); “A política republicana" (p.78-80); "País rico" (p.140-141); "Sobre a carestia" (p.191-194). Em Bagatelas (1956b), "No ajuste de contas" (p.89-96), "Da minha cela" (p.97-106) e "A nossa situação" (p.293-299). Em Vida urbana (1956d), a crônica "O novo manifesto" (p.74-75). Ainda tratam da República o romance Numa e a ninfa (1950a) e a sátira Os bruzundangas( 1995d).
\end{abstract}

\section{REFERÊNCIAS BIBLIOGRÁFICAS}

FERREIRA FILHO, João Antônio

Calvário e porres do pingente Afonso Henriques de Lima Barreto. Rio de Janeiro: Civilização Brasileira. 1977

\section{ARTAUD, Antonin}

Os escritos de Antonin Artaud. Tradução, prefácio, seleção e notas, Claúdio Willer. Porto Alegre: L\&PM. (Col. Rebeldes \& Malditos, 5). 1983

ASSIS, Machado de

O alienista. São Paulo: Ed. Três. (Col. Obras Imortais da Nossa Literatura). 1972

BANDEIRA, Esmeraldino O. T.

Curso de Direito Penal Militar. Rio de Janeiro: Francisco Alves. 1913

BARBOSA, Francisco de Assis

Lima Barreto e a reforma da sociedade. Rio de Janeiro: Pool. 1987

BARBOSA, Francisco de Assis

A vida de Lima Barreto. Rio de Janeiro: J. Olympio. 1981

BOSI, Alfredo

Lima Barreto. In: Bosi, Alfredo. História concisa da literatura brasileira. São Paulo: Cultrix. p.316-324. 1994

BOSI, Alfredo

As letras na Primeira República. In: Fausto, Boris (Org.). História geral da civilização brasileira: o Brasil republicano. v.2. Rio de Janeiro, São Paulo: Difel. 1977
BRANDÃO, João Carlos Teixeira

Questões relativas à assistência médica a alienados. Rio de Janeiro: Imprensa Nacional. 1897

BRASIL

Coleção das leis da República dos Estados Unidos do Brasil. Rio de Janeiro: Imprensa Nacional. 1907

\section{CANDIDO, Antonio}

Os olhos, a barca e o espelho. In: Candido, Antonio. A educação pela noite e outros ensaios. São Paulo: Ática. p.39-50. 1997

\section{CARRARA, Sérgio}

O crime de um certo Custódio e o surgimento do manicômio judicial no Brasil. Dados, Rio de Janeiro: v.34, n.2, p. p.279-301. 1991

CARVALHO, José Murilo de A monarquia brasileira. Rio de Janeiro: Ed. Livro Técnico. 1993

CARVALHO, José Murilo de Os bestializados: o Rio de Janeiro e a República que não foi. São Paulo: Companhia das Letras. 1987

COSTA, Jurandir Freire

Ordem médica e norma familiar. Rio de Janeiro: Graal. 1989

DOSTOIÉVSKI, Fiodor M.

Recordações da casa dos mortos. Rio de Janeiro: Francisco Alves. 1988

ENGEL, Magali Gouveia

A loucura na cidade do Rio de Janeiro: idéias e 
vivências (1830-1930). Tese (Doutorado) Universidade de Campinas, Campinas. 1995

FOUCAULT, Michel

Doença mental e psicologia. Rio de Janeiro: Tempo Brasileiro. 1996a

\section{FOUCAULT, Michel}

Genealogia del racismo. Buenos Aires: Altamira. 1996b

FOUCAULT, Michel

Microfísica do poder. Rio de Janeiro: Graal. 1995a

FOUCAULT, Michel

História da loucura. São Paulo: Perspectiva. 1995b

FOUCAULT, Michel

O que é um autor? Lisboa: Vega. 1992

LIMA BARRETO, Afonso Henriques de Clara dos Anjos. São Paulo: Ática. $1995 \mathrm{a}$

LIMA BARRETO, Afonso Henriques de Recordações do escrivão Isaías Caminha. São Paulo: Ática. 1995b

LIMA BARRETO, Afonso Henriques de Triste fim de Policarpo Quaresma. São Paulo: Ática. 1995 c

LIMA BARRETO, Afonso Henriques de Os bruzundangas. São Paulo: Ática. 1995d

LIMA BARRETO, Afonso Henriques de Diário íntimo. In: Barreto, Lima. Um longo sonho do futuro. Rio de Janeiro: Graphia. p. 7-150. 1993

LIMA BARRETO, Afonso Henriques de Vida e morte de M.J. Gonzaga de Sá. Belo Horizonte: Garnier. 1990a

LIMA BARRETO, Afonso Henriques de Contos reunidos. Belo Horizonte: Garnier. 1990b

LIMA BARRETO, Afonso Henriques de Cemitério dos vivos. São Paulo: Brasiliense. 1956a

LIMA BARRETO, Afonso Henriques de Bagatelas. São Paulo: Brasiliense. 1956b

LIMA BARRETO, Afonso Henriques de Feiras e mafuás. São Paulo: Brasiliense. 1956c

LIMA BARRETO, Afonso Henriques de Vida urbana. São Paulo: Brasiliense. p.74-76. 1956d
LIMA BARRETO, Afonso Henriques de Correspondência. 2 t. São Paulo: Brasiliense. $1956 \mathrm{e}$

LIMA BARRETO, Afonso Henriques de Marginalia. São Paulo: Brasiliense. 1956f

LIMA BARRETO, Afonso Henriques de Coisas do reino de Jambom. São Paulo: Brasiliense. p.170172. $1956 \mathrm{~g}$

LIMA BARRETO. Afonso Henriques de Impressões de leituras. São Paulo: Brasiliense. p.236-244. 1956h

LIMA BARRETO, Afonso Henriques de Histórias e sonhos. Porto Alegre: Graf. Ed. Brasileira. 1951

LIMA BARRETO, Afonso Henriques de Numa e a ninfa. Rio de Janeiro: Graf. Ed. Brasileira 1950a

LIMA BARRETO, Afonso Henriques de Aventuras do dr. Bogoloff. Porto Alegre: Graf. Ed. Brasileira. 1950b

MACHADO, Roberto et al.

Danação da norma: a medicina social e constituição da psiquiatria no Brasil. Rio de Janeiro: Graal. 1978

\section{MICELI, Sergio}

Poder, sexo e letras na República Velha. São Paulo: Perspectiva. 1977

MOREIRA, Juliano

Notícia sobre a evolução da assistência a alienados no Brasil. Arquivo Brasileiros de Neuriatria e Psiquiatria, Rio de Janeiro, ed. especial. 1955

NERVAL, Gérard de

Aurélia. São Paulo: Iluminuras. 1991

RIO DE JANEIRO. Secretaria Municipal de Educação e Cultura

O Rio de Janeiro de Lima Barreto: catálogo de exposição. Rio de Janeiro. 1983

SCHEFF, Thomas J.

Razão e saúde mental: algumas implicações do pensamento psiquiátrico. In: Forti, Laura (Org.). La otra locura, mapa antológico de la psiquiatria alternativa. Barcelona: Tusquets. 1976

VELLOSO, Mônica Pimenta

As tradicões populares na Belle Époque carioca. Rio de Janeiro: Funarte. 1988 


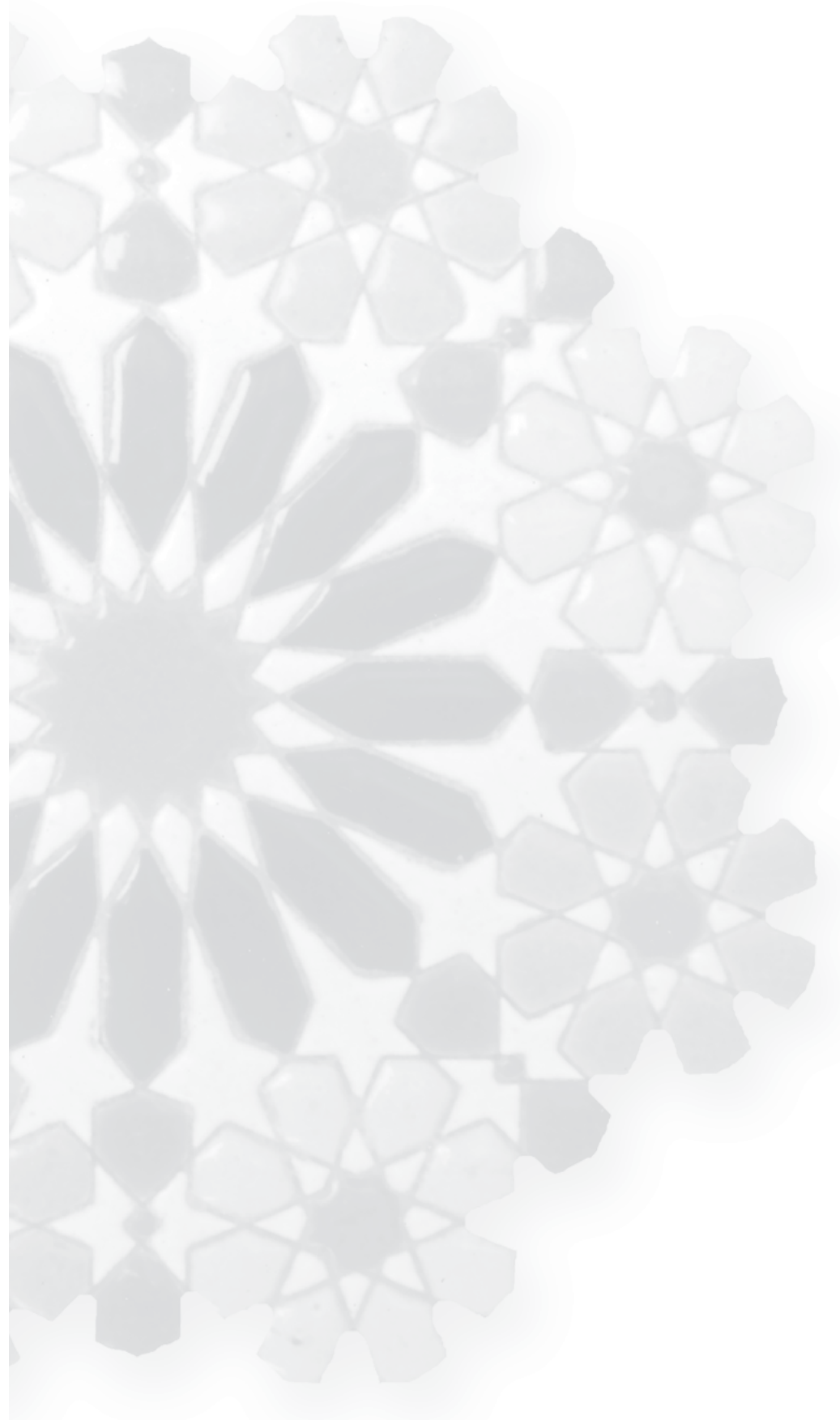

